\title{
The Reception of Petrarch's Africa in Fascist Italy
}

\author{
Samuel Asad Abijuwa Agbamu' ${ }^{1}$ (D)
}

Accepted: 15 November 2020 / Published online: 5 February 2021

(C) The Author(s) 2021

\begin{abstract}
In his 1877 Storia della letteratura (History of Literature), Luigi Settembrini wrote that Petrarch's fourteenth-century poem, the Africa, 'is forgotten ...; very few have read it, and it was judged-I don't know when and by whom - a paltry thing'. Yet, just four decades later, the early Renaissance poet's epic of the Second Punic War, written in Latin hexameters, was being promoted as the national poem of Italy by eminent classical scholar, Nicola Festa, who published the only critical edition of the epic in 1926. This article uncovers the hitherto untold story of the revival of Petrarch's poetic retelling of Scipio's defeat of Hannibal in Fascist Italy, and its role in promoting ideas of nation and empire during the Fascist period in Italy. After briefly outlining the Africa's increasing popularity in the nineteenth century, I consider some key publications that contributed to the revival of the poem under Fascism. I proceed chronologically to show how the Africa was shaped into a poem of the Italian nation, and later, after Italy's invasion of Ethiopia, of Italy's new Roman Empire. I suggest that the contestations over the significance of the Africa during the Fascist period, over whether it was a national poem of Roman revival or a poem of the universal ideal of empire, demonstrate more profound tensions in how Italian Fascism saw itself.
\end{abstract}

\section{Introduction}

Petrarch's (1304-1374) Neo-Latin epic of the Second Punic War, the Africa, which he began around 1337 or 1338, has been called 'the birth of Humanism's dream' by the Italianist Aldo Bernardo. ${ }^{1}$ This poem, which, even though incomplete, saw

\footnotetext{
1 A. Bernardo, Petrarch, Scipio, and the "Africa": The Birth of Humanism's Dream, Baltimore, 1962. For a recent survey of the long debate over the fraught term of 'Humanism', see A. Lee, Humanism and Empire: The Imperial Ideal in Fourteenth-Century Italy, Oxford, 2018, pp. xiii-xxii.
}

Samuel Asad Abijuwa Agbamu samuel.agbamu@gmail.com

1 King's College London, London, UK 
Petrarch laureated in Rome in 1341, is frequently considered to be a key text in mediating between antiquity and modernity. ${ }^{2}$ Despite such historical significance and the high regard in which the poem was held in Petrarch's own day, the Africa was all but forgotten in Italy after his death and the unfinished epic's posthumous publication, until pockets of discussion and criticism started to re-emerge in the nineteenth century. This increasing interest in the poem, running through the Risorgimento period, bore its first major fruit with the publication in 1874 of Agostino Palesa's (1809-1873) translation, the first to translate the entire epic into Italian. The resurgence of the Africa reached a highpoint in Italy during the ventennio fascistathe twenty years of Fascist rule (1922-1943). This article considers the reasons for this 'renaissance' of the Africa under Fascism.

Scholars, such as B. G. Martin and D. Medina Lasansky, have explored Fascism's celebration of Petrarch. Lasansky shows how he was mobilized for Fascism's promotion of a mythologized Middle Ages, or medioevo, while Martin demonstrates the ways in which the poet was incorporated in Fascism's cult of romanità-cultural and political invocations of the spirit of ancient Rome-and how this was used to buttress nationalist and imperialist ideology. ${ }^{3}$ It remains to be seen, however, how the layers of the reception history of Petrarch's Africa, in particular, contributed to Fascist Italian ideologies of modernity, nation and empire, and where the special significance of this epic lay for Fascist ideologues. I argue that Petrarch's Africa was made amenable to Fascist ideology though its apparent prefiguration of Fascism's project to, in Joshua Arthurs's words, 'excavate modernity' from among the ruins of ancient Rome, in order to enact a new beginning for Italy under a Fascism inspired by the myth of Rome, a process underpinned by the hope of the resurgence of the Italian nation through the revival of a Roman empire. ${ }^{4}$ In these ways, Fascism was able to reshape this fourteenth-century poem into an epic of the Italian nation, reborn with the recovery of the spirit of Rome.

This article focuses on the interest in Petrarch's Africa during the twenty years of Fascist rule in Italy as a way into exploring more broadly the Fascist historical imaginary's relationship with ideas of modernity and antiquity, nation and empire. I am also interested in the relationship between Petrarch's characterization as a medieval poet and his representation as a scholar who revived antiquity and, in so doing, brought about the advent of modernity. Umberto Eco wrote that classical antiquity is

\footnotetext{
2 E.g. G. Mazzotta, 'Petrarch's Confrontation with Modernity', in The Cambridge Companion to Petrarch, ed. A. R. Ascoli and U. Falkeid, Cambridge, 2015, pp. 221-38. See, however, J. Simpson, Oxford English Literary History, 1350-1547: Reform and Cultural Revolution, Oxford, 2002, pp. 12190, which challenges the interpretation of Petrarch as an initiator of modernity. For Petrarch as a follower of earlier humanists, see also R. Witt, 'In the Footsteps of the Ancients': The Origins of Humanism from Lovato to Bruni, Leiden, 2000, pp. 230-91. For Petrarch's sources, see F. Galligan, 'Poets and Heroes in Petrarch's Africa: Classical and Medieval Sources', in Petrarch in Britain: Interpreters, Imitators, and Translators over 700 Years, ed. P. Hainsworth et al., Oxford, pp. 85-93.

3 D. M. Lasansky, The Renaissance Perfected: Architecture, Spectacle, and Tourism in Fascist Italy, University Park PA, 2004; B. G. Martin, 'Celebrating the Nation's Poets: Petrarch, Leopardi, and the Appropriation of Cultural Symbols in Fascist Italy', in Donatello Among the Blackshirts: History and Modernity in the Visual Culture of Fascist Italy, ed. C. Lazzaro and L. J. Crum, Ithaca NY, 2005, pp. 187-202.

4 For 'excavating modernity', see J. Arthurs, Excavating Modernity: The Roman Past in Fascist Italy, Ithaca NY, 2012.
} 
an ideal that is held up as an exemplum, while the Middle Ages is a concept that we continue to live with and within. ${ }^{5}$ How then does Petrarch's classicism fit in with the myth of Rome promoted by Fascist romanità? While much scholarship has attended to Petrarch's apparent modernity and his role in shaping the concept of 'antiquity, ${ }^{6}$ and Bernhard Regn and Gerhard Huss argue that the Africa's return to antiquity set a blueprint for modernity, ${ }^{7}$ it remains to be seen how the tensions between antiquity and modernity in Petrarch's writing, especially in the Africa, foreshadow the contradictions of Italian Fascism's historical imaginary. I suggest that for the Fascist Italian literary-historical imaginary, there was something special about the Africa and this specific significance contributed to what was perhaps the most spectacular manifestation of Fascist romanità: Carmine Gallone's (1885-1958) Scipione l'Africano.

I first provide some historical background to the reception of Petrarch's Africa under Fascism by looking back to the increasing interest in the poem in nineteenthand early twentieth-century Italian literary scholarship. I then chart the reception of Petrarch's epic under Fascism by highlighting three key moments which cluster around a number of publications significant to the Africa's reception: the publication of Nicola Festa's (1866-1940) critical edition of the Africa in 1926, accompanied by his Saggio sull "Africa" del Petrarca of the same year; Enrico Carrara's (1871-1958) 1930 abridgement and translation of the epic for use in schools; and Carmine Gallone's (1885-1973) 1937 epic film of the Second Punic War, Scipione l'Africano, which shows clear-though implicit—engagement with Petrarch's epic within a wider context of romanità being mobilized in support of Fascist Italy's imperial mission in Africa. At each of these moments, the Africa is moulded into the service of the elaboration of Fascist ideologies of modernity, nation and empire, ideological strands unpicked in this article.

\section{The 'Renaissance' of Petrarch's Africa in the Long Nineteenth Century}

Editions of Petrarch's Africa - both in the original and in translation-published in Italy during the nineteenth and twentieth centuries are clustered around three decades: the 1870s, 1920s and 1930s. The key publications of these decades are Palesa's first complete translation into Italian in 1874, republished a further three times, and Festa's critical edition of 1926, the first and only one to date, which remains the most cited edition of the poem. ${ }^{8}$ This latter edition was published as the first volume of a government-initiated project to edit the complete works of Petrarch, planned in

\footnotetext{
${ }^{5}$ U. Eco, Faith in Fakes: Essays, London, 1986, pp. 67-8.

6 A. R. Ascoli and U. Falkeid, 'Introduction', in The Cambridge Companion to Petrarch, ed. A. R. Ascoli and U. Falkeid, Cambridge, 2015, pp. 1-9; Bernardo, Petrarch, Scipio, and the "Africa" (n. 1 above); Mazzotta, 'Petrarch's Confrontation' (n. 2 above); T. Mommsen, 'Petrarch's Conception of the "Dark Ages"', Speculum, 17, 1942, pp. 226-42.

7 G. Regn and B. Huss, 'Petrarch's Rome: The History of the Africa and the Renaissance Project', $M L N$, 124, 2009, pp. 86-102 (102).

${ }^{8}$ Petrarch: A Critical Guide to the Complete Works, ed. V. Kirkham and A. Maggi, Chicago, 2009, p. 384.
} 
1904 as part of Petrarch's six-hundredth anniversary celebrations, but interrupted by the First World War. ${ }^{9}$ In order to understand why these decades should have seen such a Petrarchan 'renaissance', we must look back earlier.

A significant moment in the nineteenth-century revival of Petrarch's Africa must be sited at the publication of Ugo Foscolo's (1778-1827) 1823 Essays on Petrarch. Foscolo, an anti-Austrian, Greek-born Italian patriot, a novelist, poet and playwright of the late eighteenth and early nineteenth century, was widely read during the Risorgimento and was later viewed as a proto-Fascist by literary historians close to the regime. ${ }^{10}$ Foscolo, like Petrarch, was an exile. He went into voluntary exile to London in 1816, where he remained until his death in 1827. It was during this time that he turned away from creative works and focused on his essays, written in English, on Italian literary history. ${ }^{11}$ Those on Petrarch, written with the help of and dedicated to his friend, benefactor and fellow scholar, Barbarina Brand, Lady Dacre, ${ }^{12}$ whose translations of Petrarch append the volume, form part of this literary-historical project.

The slim volume opens with an epigrammatic quote taken from the sixth book of the Africa: ${ }^{13}$

Irrequietus homo perque omnes anxius annos

Ad mortem festinat iter. Mors optima rerum ...

[Restless man, anxious through all his years,

Hurries long the road to death: death, the best of things ... ]

In the appendix, Foscolo includes a translation, purportedly by Lord Byron, of this section of Book Six, ${ }^{14}$ and elsewhere in the volume Foscolo uses this episode to argue against the notion that Petrarch had rediscovered Silius Italicus's Punicain fact, recovered seventy-six years after Petrarch's laureation—and passed Silius's

\footnotetext{
9 V. Rossi, 'L'Edizione Nazionale delle Opere di Francesco Petrarca', in Convegno Petrarchesco, tenuto in Arezzo ... MCMXXVIII, Arezzo, 1930, pp. 88-96 (88).

10 See S. Lanfranchi, 'La réception de Foscolo dans 1'Italie fasciste', Laboratoire italien, 5, 2004, pp. 197-219. See also the appendices to Lanfranchi's doctoral thesis for publications of Foscolo's works during the ventennio: S. Lanfranchi, La recherche des précurseurs. Lectures critiques et scolaires de Vittorio Alfieri, Ugo Foscolo et Giacomo Leopardi dans l'Italie fasciste, PhD diss., Université Paris VIII Vincennes-Saint-Denis, 2008, pp. 429-35.

11 See R. A. Walsh, Ugo Foscolo's Tragic Vision in Italy and England, Toronto, 2014, pp. 82-92, on Foscolo's writings in exile.

12 See S. Parmegiani, Ugo Foscolo and English Culture, London, 2011, p. 3, on Lady Dacre's support of Foscolo.

13 All Latin of the Africa comes from Festa's 1926 edition, unless otherwise stated. See Ugo Foscolo, Essays on Petrarch, London, 1823. All translations from the Africa are my own, unless otherwise stated. I also consulted Petrarch's Africa, transl. T. G. Bergin and A. Wilson, New Haven, 1977.

14 These lines are translated, ostensibly by Byron, as: 'But man in restless dreams spends all his years, I and shortens life with death's encroaching fears', cited in Foscolo, Essays (n. 13 above), p. 217. The lament of Mago seems to be one of a possible two passages from the Africa to have been published in Petrarch's lifetime-see S. Marchesi 'Petrarch's Philosophical Epic (Africa)', in Petrarch: A Critical Guide to the Complete Works, ed. V. Kirkham, A. Maggi, 2009, pp. 113-30 (113). Mago's soliloquy has also been interpreted as a Christianization of the Carthaginian. See A. Bernardo, 'Petrarch's Autobiography: Circularity Revisited', Annali d'Italianistica, 4, 1986, pp. 45-72 (57-9).
} 
words off as his own. ${ }^{15}$ These lines of the Africa, taken from the Carthaginian commander Mago's monologue as he is dying at sea on his way back from Italy to defend Carthage against Scipio's invasion, must have had especial emotional resonance to the exiled patriot. Mago's words bear a strong resemblance to Foscolo's 1803 sonnet $A$ Zacinto, in which the poet mourns that he will die in exile, away from the Greek island of his birth, Zakynthos. ${ }^{16}$ He compares himself to Odysseus, although, unlike Odysseus, who is able to eventually return to Ithaca after the Trojan War, Foscolo sees little hope of return to Zakynthos. William Kennedy argues that Petrarch's vernacular lyric played an important role in the early modern construction of European national sensibilities, ${ }^{17}$ yet in Foscolo's Essays it is the Africa which is foregrounded by Foscolo. Here, the Africa is made to speak of a Romantic nostalgia for one's homeland. As we will see, the ideology linking the Africa and the notion of nationhood will be more aggressively elaborated during the ventennio, the twentyyear period of Fascist rule of Italy.

Perhaps it is little wonder, in this light, that the decades following the unification of Italy saw a marked upswing in Italian scholarly interest in Petrarch and, in contrast to earlier periods, his Africa. Prior to the second half of the nineteenth century, there had been a number of Italian translations of selected books of the epicfor example, Fabio Marretti's 1570 translation of Books One to Three, and Egle Euganea's 1776 translation of Book One. ${ }^{18}$ Yet, in 1874, three publications of note appeared in Italy. These, no doubt, owed much to Léon Pingaud's 1872 edition, published in Paris and the first scholarly edition of the epic. Two years later, Francesco Corradini (1820-1888) published his own edition of the epic to coincide with the anniversary of the poet's death, and that same year, Agostino Palesa published the first translation into Italian of the poem in its entirety. ${ }^{19}$ Palesa's translation would go on to be reprinted in 1904, to coincide with the sixth centenary of Petrarch's birth, and in 1930, a year to which I will return later in this article. The fortuitous timing of the fifth centenary of Petrarch's death, falling as it did within three years of Rome becoming the capital of the new nation of Italy, goes a long way to explaining this spike in publications relating specifically to the Africa. Nevertheless, the anomalously intense attention paid to the Africa in this period, in contrast to the reception histories of Petrarch's other works, particularly his vernacular verse, needs further elaboration.

\footnotetext{
15 Foscolo, Essays (n. 13 above), pp. 99-100.

16 Ugo Foscolo, Scelte opere di Ugo Foscolo, Florence, 1835, p. 115.

17 W. J. Kennedy, The Site of Petrarchism: Early Modern National Sentiment in Italy, France, and England, Baltimore, 2003; see p. 4 on the anachronism of early modern 'nationalism' and on the more accurate 'national sentiment'.

18 L'Africa del Petrarca, in ottava rima, insieme col testo latino, fedelissimamente tradotta da M. Fabio Marretti, Venice, 1570; Dell'Africa di Francesco Petrarca libro primo, volgarizzato da Egle Euganea, Padua, 1776. Euganea was the pseudonym of Countess Francesca Roberti Franco.

${ }^{19}$ De poemate F. Petrarchae cui titulis est Africa, ed. Léon Pingaud, Paris, 1872; Africa Francisci Petrarchae nunc primum emendate, ed. Francesco Corradini, Padua, 1874; L'Africa recata in versi italiani dal dottor Agostino Palesa, Padua, 1874.
} 
To understand this shift in favour of the Africa at the end of the nineteenth century, I turn to the philosopher Armando Carlini's (1878-1939) 1902 Studio su 'L'Africa' di Francesco Petrarca. The study falls into two halves: the first provides background to the composition of the Africa, while the second supplies a critical analysis of the poem. Carlini selects an epigrammatic quotation from Luigi Settembrini's 1887 Storia della letteratura to open his study of Petrarch's epic: the Africa 'is forgotten ...; very few have read it, and it was judged-I don't know when and by whom-a paltry thing'. ${ }^{20}$ The implication of Settembrini's words, and of Carlini's citation of them, is that such an appraisal is misplaced, and that Carlini's contribution will go some way to correcting the low regard in which the Africa was held in the centuries between its publication and the late nineteenth century. Granted that Carlini's slim volume was published just two years before the sixth centenary of Petrarch's birth, the preface is telling in terms of why the decades either side of the turn of the twentieth century saw such renewed interest in the Africa. For Carlini, Latin thought was, until the late Middle Ages, the 'glorious custodian of Italian thought'. Such 'Latin thought' guided the Italian people to achieve a patria consciente - a homeland aware of itself-by reminding them that they were 'the sons of Rome, who commanded the world by the power of their arms and their ingenuity'. ${ }^{21}$ The educative function of such Latin thought, represented by Petrarch's Africa, in the pursuit of a national conscience is highlighted here. Carlini mentions an additional factor contributing to the significance of the Africa within its historical context: its mediating function between the world of the Middle Ages and that of modernity. He writes that it was at the end of the Middle Ages and at the dawn of the modern era that Italian art rose from the ancient ruins 'fresher and more graceful than ever', and that Latin thought 'continued to raise new art in a new way'. ${ }^{22}$ In other words, the Latin language was a powerful vehicle for cultural renewal and innovation.

According to Carlini, Petrarch's Africa had been buried under accumulated layers of neglect and ignorance. Not only were there no editions of the epic (according to him) published between the sixteenth and nineteenth centuries, but the publications and translations of the nineteenth century confused things even more, and it took Francesco Corradini's 1874 edition of the Africa to correct some of the missteps of Pingaud's 1872 publication. ${ }^{23}$ Even Palesa's translation is, for Carlini, too loose with the Latin. The overarching sense of Carlini's study, therefore, is that the Africa was a poem which had suffered from the neglect and ignorance of centuries of scholarship, and now, at the turn of the century, at the dawn of the modern nation-state of Italy, and on the eve of Petrarch's sixth centenary, it was time to excavate the epic from the ruins under which it had been buried. If this was a process begun by Corradini

\footnotetext{
${ }^{20}$ L. Settembrini, Storia della letteratura italiana, Naples, 1877, p. 199, cited in Armando Carlini, Studio sul' 'L'Africa' di Francesco Petrarca, Florence, 1902, p. 2.

21 Carlini, Studio (n. 20 above), p. 1.

22 Ibid.

23 Ibid., pp. 1-9.
} 
and Palesa, and promoted by Carlini, then it was brought to completion with the publication of Festa's critical edition in 1926.

\section{Italy's National Poem: The Africa from 1926 to 1928}

After Mussolini's March on Rome in 1922 and his subsequent conquest of the state, there was a concerted drive to formulate a new, Fascist culture for Italy. Scholars have long noted that the cult of ancient Rome played a significant part in this construction of a Fascist Italian culture. ${ }^{24}$ At the same time, in the late 1920s, there was a discernible push to promote post-classical Italian literary history. For example, in 1929, the Congresso Mondiale delle Biblioteche e di Bibliografia was held at venues across Italy. The 1928 Petrarch festival must also be seen within this context of a general promotion of Italian literature and, at the same time, a celebration of the recent publication of the first volume of the Edizione nazionale delle opere di Francesco Petrarca. This was Nicola Festa's critical edition of the Africa, dedicated to the King of Italy, Vittorio Emanuele III. Festa, Professor of Greek at the University of Rome, La Sapienza, would later gain further ideological prominence in Fascist Italy when he translated Mussolini's speeches announcing victories over Ethiopia in 1935 and 1936 into Latin. ${ }^{25}$ In preparing his edition of Petrarch's poem, Festa consulted about twice as many manuscripts of the Africa-seventeen complete manuscripts and a number of fragmentary ones-as Pingaud or Corradini. ${ }^{26}$ Even so, Festa came upon further manuscripts of the poem, subsequent to the publication of his critical edition. ${ }^{27}$

To accompany his critical edition, Festa published his Saggio sul' "Africa” del Petrarca (1926). In the prefatory dedication to Teresina, daughter of Giovanni Gentile, seen as 'the philosopher of Fascism', Festa expresses the hope that the Africa would become 'our national poem' and one of Roman rebirth. He suggests that the time for 'the re-flourishing of immortal youth' had come, writing that it was no coincidence that 'this poem of Roman triumph had once again come to light on a day when the name of Rome resounds as something mystical and august', presumably now that Fascism had come to power. Festa's volume outlines the history of the text, its origins and circulation, with a scholarly rigour that has guaranteed the

\footnotetext{
${ }^{24}$ See, e.g., M. Cagnetta, Antichisti e Impero Fascista, Bari, 1979; J. Arthurs, Excavating Modernity: The Roman Past in Fascist Italy, Ithaca NY, 2012; M. Stone, 'A Flexible Rome: Fascism and the Cult of romanità', in Roman Presences: Receptions of Rome in European Culture, 1789-1945, ed. C. Edwards, Cambridge, 1999, pp. 205-20; R. Visser, 'Fascist Doctrine and the Cult of Romanità', Journal of Contemporary History, 27:1, 1992 pp. 5-22.

${ }^{25}$ Benito Mussolini, La Fondazione dell'Impero: nei discorsi del duce alle grandi adunate del populo italiano con una traduzione latina di Nicola Festa, Naples, 1936; H. Lamers 'Latinizing Mussolini's Message: Nicola Festa's Latin Translation of the "Proclamation of Empire" (1936/7)', International Journal of the Classical Tradition, 24, 2017, pp. 198-218.

${ }^{26}$ E. Z. D. Ellis, Petrarch's Africa I-IV: A Translation and Commentary, unpublished MA thesis, Baylor University, 2007, p. 4.

${ }^{27}$ Nicola Festa, 'Due nuovi codici dell'"Africa', in Parma a Francesco Petrarca, ... 1934-XII, Atti del Convegno, Parma, 1934, pp. 45-78.
} 
work's continuing value to Petrarchan scholarship. The ideological commitments of the study are, however, occasionally made explicit. For example, in Chapter Three, a 'critical examination of the poem', Festa writes:

For Petrarch, the story of Scipio and the story of Rome acquire, bit by bit, a transcendental value; taking place in universal history, they [the stories] enter into a great conception of the designs of providence in respect to the destiny of the human race. And with this, the poet also raises and transforms himself; he becomes a philosopher, he becomes a prophet. ${ }^{28}$

Here, the ideological stakes of Petrarch's poem for Festa are made clear. Scipio attains the character of Italy's 'synecdochic hero', ${ }^{29}$ a figure made to stand in for the past, present and future of the nation, expanded further here to the entire human race. The Punic Wars take their place in the continuum of universal history, a providential trajectory of human progress, a process necessitating Italian triumph over Africa. The evident implication is that Fascism's triumph also represents part of this process, in which case the question is whether Petrarch then becomes a philosopher and prophet of Fascism. Festa explicitly asserts that it is not right to call the Africa 'the poem of humanism', thus setting his interpretation of the epic against that of Giuseppe Piazza, who published a study of the Africa in 1906, entitled Il poema dell'umanesimo. Instead, it, along with Dante's Divine Comedy, is testament to the greatness of the Middle Ages, while its poet-Petrarch-is everyday brought closer to 'the place of honour that he is owed in the general story of European civilization'. ${ }^{30}$ How precisely this runs counter to Piazza's conception of the Africa as a humanist poem remains unclear. It is, however, significant that Festa is self-consciously drawing a line between Piazza's interpretation of the Africa and his own, a decisive break to separate Piazza's pre-1922 Africa from Festa's Africa of the ventennio.

The trajectory of the progress of European civilization, from antiquity to modernity, is highlighted later on in Festa's volume. He writes:

Just as Ennius was called 'the other Homer', Petrarch was 'the other Ennius', a third life is given to Homer in the modern era in three different moments of history-the same poetry, the same spirit is shown. ${ }^{31}$

\footnotetext{
${ }^{28}$ Nicola Festa, Saggio sul' "Africa" del Petrarca, Palermo, 1926, p. 71: 'Ma nella mente del Petrarca la storia di Scipione e la storia di Roma acquistano a poco a poco un valore transcendentale; prendono posto nella storia universale, entrano in una concezione grandiose dei disegni della Provvidenza rispetto ai destini del genere umano. E con questo, anche il poeta si eleva e si transfigure; diviene filosofo, diviene profeta.' See Enrico Carrara, Da Rolando a Morgante, Turin, 1932, p. 130, in which the Africa's Scipio is represented as a universal, Christian 'model of humaneness', triumphing over African impiety.

${ }^{29}$ On Aeneas as Italy's 'synechdochic hero', see P. Hardie, The Epic Successors of Virgil, Cambridge, 1993, p. 4.

${ }^{30}$ Festa, Saggio (n. 28 above), p. 74.

${ }^{31}$ Ibid., p. 87: 'In conclusione: come Ennio fu detto alter Homerus, il Petrarca sarà Ennius alter; a Omero è assegnata una terza vita nell'età moderna; in tre momenti di versi della storia, la stessa poesia, lo stesso spirito si manifesta'. See A. Galletti, 'La modernità del Petrarca (discorso inaugurale)', Parma a Francesco Petrarca, ... 1934-XII, Atti del Convegno, Parma, 1934, pp. 31-43. For the reception of
} 
Festa emphasizes Petrarch's status as a modern incarnation of the spirit of antiquity, which transmigrates from Greece to Rome and to Italy as a nation. Similarly, he later expounds on the significance of the poem having been written in Latin.

These notes suffice to demonstrate that the Africa is best considered as a 'sacred poem, to which heaven and earth have given a hand' and according to the intention of the author must be our great national poem; composed in that wonderful 'lingua nostra', which passes for a dead language, only among the ignorant and among the conceited crowd populating the limbo of half culture. $^{32}$

The promotion of Latin as a living language is read within the context of its revival during the ventennio, a project in which Festa played an active role. ${ }^{33}$ Latin assumed the status of a national language which was able to give voice to universal sentiments as expressed in the cosmic significance of Petrarch's poem, especially Scipio's dream in the first and second books of the epic, and Ennius's vision in the ninth.

Festa's work on the Africa drew attention in the prominent Jesuit periodical La Civiltà Cattolica. Jan Nelis has shown how the image of Roman antiquity presented by this periodical was often at odds with that of Fascist romanità, although in the wake of the Lateran Pact (1929), this started to change. From the early 1930s, authors in La Civiltà began increasingly to accommodate Fascist narratives of pagan ancient Rome as the necessary preparation for the advent Christianity. ${ }^{34}$ In 1927 , an article on Petrarch's Africa, written in the wake of Festa's critical edition, was published in La Civiltà Cattolica. In this article, the author disagrees with Festa's assertion that the Africa 'stands with the Divine Comedy as a testament to the greatness of a marvellous age, the Middle Ages' and that Petrarch's epic ought to be considered 'a sacred poem', which 'according to the intention of the author [Petrarch] ought to become our great national poem'. ${ }^{35}$ For the author of the La Civiltà article, the Africa, while perhaps Petrarch's 'most classical' poem, was by no means the 'mature fruit of la scienza Latina of Petrarch and the Middle Ages', failing to reach

\section{Footnote 31 (continued)}

Ennius as 'the second Homer' in the Renaissance, see N. Goldschmidt 'Absent Presence: pater Ennius in Renaissance Europe', Classical Receptions Journal, 4, 2012, pp. 1-19.

${ }^{32}$ Festa, Saggio (n. 28 above), p. 93. 'Bastano questi cenni per mostrare che anche l'Africa vuol essere considerata come «poema sacro, al quale ha posto mano e cielo e terra» e secondo l'intenzione dell'autore dovrebbe essere il nostro grande poema nazionale; composto in quella meravigliosa «lingua nostra», che passa per lingua morta, solo presso gl'ignoranti e fra la turba presuntuosa popolante il limbo della mezza cultura.' NB. the quotation from Dante, Paradiso, XXV.1-2.

33 H. Lamers et al., 'Neo-Latin Literature-Italy: Fascism (1922-1943)', in Brill's Encyclopaedia of the Neo-Latin World: Micropaedia, ed. by P. Ford et al., Leiden, 2014, pp. 1091-6; H. Lamers and B. ReitzJoosse, 'Lingua Lictoria: the Latin Literature of Italian Fascism', Classical Receptions Journal, 8, 2016, pp. 216-53.

34 J. Nelis, 'Catholicism and the Italian Fascist Myth of Romanità: Between Consciousness and Consent', Historia Actual Online, 17, 2008, pp. 139-46.

35 'L'“Africa” del Petrarca', La Civiltà Cattolica, 78:2, 1927, pp. 426-432 (432), citing Festa, Saggio (n. 28 above). 
the height of Dante's art, the equal neither of Homer nor of Virgil. ${ }^{36}$ Thus, the year after the publication of Festa's critical edition, we see the value of the Africa being contested. For the Jesuit author of La Civiltà, the Africa can be characterized as a lengthy footnote to Petrarch's works, 'more known than read by the admirers of the poet'. ${ }^{37}$ For Festa, having wrested the poem from the hands of liberal humanism, it is 'sacred' and 'universal'; and the pagan, saint-like figure of Scipio Africanus is a challenge to the spiritual hegemony of the Catholic Church in Italy. After the Lateran Pact, as the cruciform and the fasces were brought into closer cooperation in a cultura della destra (culture of the right), the Catholic ambivalences towards the figure of Scipio, and Fascist romanità more generally, were gradually suppressed.

A further step in the process of the institutionalization of Petrarch and his Africa in Fascist Italy took place in 1928 in the town of Petrarch's birth, Arezzo. That year, in the wake of the publication of the first volume of the Edizione nazionale of Petrarch's complete works, the city hosted a festival celebrating the poet. Twenty-four years earlier, festivities had also been staged there to celebrate the six-hundredth anniversary of Petrarch's birth, but the 1928 event, although celebrating no anniversary in particular, was on an altogether different scale. ${ }^{38}$ This festival was part of the broader promotion of Italian literary culture and of the project of publishing critical editions of Petrarch's works. It also served to encourage tourism to Arezzo's medieval centre. Petrarch was celebrated by the city as an Aretine, having been born there in 1304, as well as living there for a period when in exile from Florence. A house identified as his birth place was renovated and opened in 1928 as a home for the Accademia Petrarca, an organization endorsed and encouraged by the central government in Rome. ${ }^{39}$ As one element of the festivities, a monument to Petrarch was inaugurated by King Vittorio Emanuele III, filmed and screened across the nation by the Fascist regime's official documentary production company, Istituto LUCE. ${ }^{40}$ The celebrations also included a two-day conference sponsored by the Accademia Petrarca and the Istituto Nazionale di Cultura Fascista (INCF), the involvement of this governmental body underscoring the regime's commitment to the Petrarchan project. $^{41}$

In the preface to the published proceedings of this conference, Petrarch was heralded as 'the eloquent resuscitator of the spirit of romanità'. ${ }^{42}$ Similarly, in the opening lecture of the conference, Eugenio Coselschi, the regional head of the INCF,

\footnotetext{
${ }^{36}$ La Civiltà Cattolica (n. 35 above).

37 Ibid., p. 426.

${ }^{38}$ For the background to this celebration, see Lasansky, Renaissance Perfected (n. 3 above), pp. 108, 125-6.

39 Ibid., p. 127.

40 LUCE's archive has been digitised and is available online. The inauguration of the Petrarch monument is film A022705- Ad Arezzo il re inaugura il monumento al Petrarca', 11/1928. For a discussion of Fascist celebrations of 'the nation's' poets, including Petrarch, and this monument, see Martin, 'Celebrating the Nation's Poets' (n. 3 above), pp. 187-202.

41 Martin, 'Celebrating the Nation's Poets' (n. 3 above), p. 187.

42 Reale Accademia Petrarca, Convegno Petrarchesco, tenuto in Arezzo il XXV e XXVI Novembre $M C M X X V I I I, 1930$, p. i: ' ... l'eloquente resuscitatore dello spirito della romanità...'
} 
praised Petrarch's patriotism and reverence of romanità. Thus, although Petrarch was a medieval poet, as these comments and the framing of the Africa show, it was not his status as a man of the 1300s for which he was celebrated, but rather his role in reviving the spirit of ancient Rome. For Festa, the Africa exemplified the significance of Petrarch as the resuscitator of romanità, bridging the vast gap between the Rome of Scipio and the Italy of Mussolini. If Festa saw the role of his work on the Africa as facilitating its accession to the status of the national poem of Italy, then it would have to be 'nationalized', so to speak. A three-hundred-page critical edition of a Latin text, costing one-hundred lire, would only ever have an impact on a small circle of specialist readers. For the Africa to ascend to the status of a national poem, it would have to reach a mass readership.

\section{The Nationalization of the Africa in the Early 1930 s}

Petrarch's 1930s began with two publications significant to the nationalization of the poet and his Africa. The literary scholar Luigi Tonelli (1890-1939) published a monograph on the life and works of Petrarch to complement his existing publications on figures such as Dante, Manzoni and D'Annunzio. This fifteen-lire paperback, which pays special attention to the psychological development of Petrarch, had a wide-ranging impact at the time. For example, it enjoyed a favourable write-up in a 1932 issue of La Civiltà Cattolica which, however, glosses over Tonelli's treatment of the Africa and perhaps predictably focuses more on Petrarch's perceived Christian mysticism. ${ }^{43}$

Later that same year, however, Enrico Carrara published his Luoghi dell' "Africa", an abridgement of Petrarch's epic, complete with an Italian translation, intended for use in schools. Its modest price of six lire allowed a broader audience, for whom the price of Festa's volume would have been prohibitively high, access to the Latin of the epic, supported by notes and a parallel translation. The passages of the Latin, comprising about one-third of the lines of the entire epic, are taken from Festa's edition. The preface to the slim volume opens with the wish voiced by Festa in his Saggio that the Africa would become the national epic of Italy. Carrara takes Tonelli's appraisal of the epic as the motivation for his own endeavour to make the Africa more accessible:

The Africa is therefore a national and Mediterranean poem, as well as a Christian and personal one ... it is finally raised from the archive of dead things and by promoting its knowledge and study, it is placed among the highest testaments of the Italian spirit. ${ }^{44}$

\footnotetext{
${ }^{43}$ Luigi Tonelli, Petrarca, Milan, 1930; 'Una nuova vita del Petrarca', La Civiltà Cattolica, 83.2, 1932, pp. 62-8.

44 Tonelli, Petrarca (n. 43 above), cited in Enrico Carrara, Luoghi dell' "Africa”, Milan, 1930, p. 5: 'Poema nazionale e mediterraneo, dunque, l'Africa, oltre che poema Cristiano e personale ... la si tolga finalmente dall' archivio delle cose morte e promovendone la conoscenza e lo studio la si ponga accanto all più alte testimonianze poetiche dello spirito italiano.'
} 
The specifically national character of the Africa, in conjunction with its universalizing synthesis of Mediterraneità and Christianity, is typical of Carrara's representation of Petrarch's poem. The Africa was, however, not simply a humanist work, according to Carrara, but at once something more universal and personal. A year after his Luoghi, Carrara published Sulla soglia dell'”Africa” (1931), a scholarly analysis, in which he characterizes the poem as one of "not only human redemption, but individual redemption'. ${ }^{45}$ A year later still, Carrara brought out a monograph on medieval Italian epic, Da Rolando a Morgante (1932). In this, he portrays the Africa as a celebration of virtue over impiety, of Italian civilization over that of Phoenician Africa, contributing to a Christianized interpretation of Roman history, and culminating in the enthronement of St Peter in Rome. ${ }^{46}$ The promotion of this poem of universal significance, celebrating the triumph of the universal hero, Scipio, underpins the motivations for Carrara's 1930 operetta scholastica. He explicitly states that the function of his abridged edition of the Africa is to inculcate school-aged children with the values of ancient Rome:

... I am convinced that through school it is possible to partially achieve these noble aims [of reviving the classicism of ancient Rome]. Our schools, as much the case in middle school as in high school, not only recognizes the classical tradition as alive and present, but shows itself as more solicitous and reverent every hour towards those works in which Latin, although far from the Ciceronian type, shows that it remains 'that wonderful lingua nostra which passes for a dead language only among the ignorant'. This was the case for Petrarch and for two ages it thus remained: a means of expression always alive, always appropriate to various and renewing cultural needs. ${ }^{47}$

In quoting Festa to highlight the Latin of the Africa as a living language and one which belongs to the Italian nation, Carrara was elevating the epic to the status of a conduit of the classical tradition, linking Roman antiquity to the schools of modern Italy through the living language of Latin. The promotion of the Africa, therefore, was a promotion not only of that 'wonderful lingua nostra', but of the poetic Italian spirit.

Carrara stresses the difficulties of the endeavour undertaken by his edition. Although, thanks to Festa's edition, he had access to a version of the Latin text which left little open to doubt, the challenges in translation are compounded by his aim to write 'tra lo stil de' moderni e'l sermon prisco' ('between modern style and ancient content'), taking these words from Petrarch's Canzoniere 40. Unlike Palesa's translation, or Agostino Barolo's which I turn to later, Carrara's version is in prose.

\footnotetext{
45 Enrico Carrara, Sulla soglia dell' "Africa”, Perugia, 1931.

46 Carrara, Da Rolando (n. 28 above), p. 130.

47 Carrara, Luoghi (n. 44 above), p. 5: ‘ ... persuaso che attraverso la scuola sia possible conseguire in parte questi nobili intenti. La scuola nostra, così la media come la superiore, non solo riconosce per viva e presente la tradizione classica, ma si apre, ognor più sollecita e reverente, a quelle opere in cui il latino, benché lontano dall'età e dal tipo ciceroniano, mostra di restare "quella meravigliosa lingua nostra, che pasa per la lingua morta solo presso gli ignoranti"; tale era per il Petrarca e per due secoli restò ancora: mezzo d'espressione sempre vivo, sempre adeguato ai vari e rinnovellantisi bisogni culturali'.
} 
There seem to be a number of reasons for this choice. Firstly, since the intended readership was at least partially middle school and high school students, Carrara might have considered prose more accessible than a verse translation. Secondly, the constraints placed by the format of the book, with Italian translations underneath the lines of Latin, may have made a prose translation more efficient with space, thus keeping the cost low. Thirdly, perhaps Carrara considered prose more appropriate to 'lo stil de' moderni' than verse.

Carrara chose passages from the Africa which 'bring to light the various aspects' of the poem. These are largely the episodes that one would expect to find in an abridged version, from the dream of Scipio in Books One and Two and the doomed romance of Massinissa and Sophonisba in Book Five, to the Battle of Zama in Book Seven and Scipio's voyage back to Italy, accompanied by Ennius, in Book Nine. In total, the luoghi are divided into thirty chapters, each helpfully supplied with a short introductory paragraph contextualizing the passage and a brief critical note at the end, underscoring a few points of interest in the text and its allusions to classical literature, as well as references to modern scholarship. Carrara's notable erudition in this regard was developed and expanded in his subsequent Sulla soglia del' "Africa". For example, in his notes to the protasis of the poem in his Luoghi, Carrara draws attention to the parallel invocations to the muses and an earthly ruler in both the Africa and in Statius's Thebaid, whereas in Sulla soglia, he has the space to expand his discussion of Petrarch's use of Statius by pointing out the echoes of the initial lines of the Achilleid in the opening of the Africa ${ }^{48}$ Carrara's work on the Africa and especially in his Luoghi demonstrates the importance that he placed on the epic in its role of conveying the use of Latin from ancient Rome to modern Italy. The primary value of the Africa, for Carrara, was to ensure that the classical tradition remained alive, and thus the promotion of its study would ensure the perpetuation of that tradition of which Petrarch was a conduit, given increased potency by the Latinity of the poem.

The significance of the Africa during the ventennio was not, however, limited to its Latinity. In 1930, Palesa's translation was republished, and in 1933, a new translation prepared by Agostino Barolo appeared. This twenty-lire paperback, its cover adorned with an image of the She-Wolf of Rome, with the shadow of a palm tree in the background, speaking to the exotic locales visited by Petrarch's epic, also uses Festa's edition of the Latin as the basis for the translation. The introduction sets out to vindicate the Africa and to right the wrongs inflicted on it by modern scholarship_prior, that is, to Festa's work. Barolo opens with the statement:

The story of our literature presents us with this truly unique and strange fact: one of our major poets - the greatest after Dante - has never been known as he deserved to be, nor has the work which its author hoped would be his greatest. $^{49}$

\footnotetext{
${ }^{48}$ Carrara, Luoghi (n. 44 above), p. 10; Da Rolando (n. 28 above), p. 7.

49 A. Barolo, L' "Africa” di F. Petrarca in versi italiani di Agostino Barolo, Turin, 1933, p. vii. 'La storia delle lettere nostre ci presenta questo fatto veramente unico e strano: di uno dei nostri maggiori poeti, - il più grande, dopo Dante-non si connobe mai, come meritava di essere e come il suo autore sperava che fosse, l'opera maggiore.'
} 
Instead, the Africa had been buried by 'preconceived hostility and deplorable incomprehension' ${ }^{50}$ By way of example, he points to De Sanctis's characterization of the Africa as a work of imitation and an overall failure. ${ }^{51}$ Barolo sees Bartoli's appraisal of the Africa as more accurate, although reducing the epic to a work of dry erudition, whose lyrical qualities are not worth attention. For Barolo, scholarly interest in the Africa took a new direction with the publication of Festa's edition. Now, it was possible to do justice to Petrarch's epic and to recognize it as a poem which 'presents us [with] a most fervid admiration of romanità, to which it is securely bound and of which it is still a part'. ${ }^{52}$ As with Festa and Carrara, for Barolo, the Africa stands as a potent symbol of romanità, the cult of ancient Rome that was so central to Fascism's self-presentation. By translating it into Italian verse, Barolo could bring a wider sector of the Italian population into contact with this poem, so important to the romanità promoted at the time. In Barolo's eyes, as with Carrara, what set his translation apart from, for example, Palesa's, republished just two years before the appearance of his own translation, was that Barolo had the benefit of using Festa's critical edition and was contributing to a broader moment in the revival of the poem. The work of Tonelli, Carrara, and Barolo on Petrarch and his Africa in the early 1930s established the conditions for the final phase in the development of the reception of the poem in Fascist Italy.

\section{Petrarch's Africa: Empire and the Masses}

In 1935, Fascist Italy invaded Ethiopia. The next year, Ethiopia had been defeated and Mussolini, in a series of speeches, had declared victory and proclaimed the rebirth of empire under the sign of the fasces. These speeches were translated into Latin by Nicola Festa and widely circulated in published form. At this time, romanità was increasingly put in service of promoting the idea that the Fascist Italian empire in Africa was the reincarnation of the Roman Empire. In this context, the wars against Rome's most formidable African enemy, Carthage, were mentioned more and more in discourses of Fascist imperial romanità. Small wonder, then, that Rome's greatest conqueror of Africa, Scipio Africanus, should have enjoyed ever more prominence in Fascism's historical imaginary at this time, and that the Africa - the poem of this previously unsung hero, since the Punica was unknown to Petrarch, and Ennius was lost-should be explicitly employed to promote Italian imperialism in Africa. ${ }^{53}$

\footnotetext{
${ }^{50}$ Barolo, L' “Africa” (n. 49 above): '... seppellita sotto la grave mora di una ostilità preconcetta e di una deplorevole incomprensione...'.

${ }^{51}$ F. De Sanctis, Storia della letteratura italiana, Naples, 1870, cited in Barolo, L' "Africa" (n. 49 above), p. xiii.

${ }^{52}$ Barolo, L' 'Africa" (n. 49 above), p. xl: 'si presenta a noi quale opera ... nell'ammirazione fervidissima verso la romanità, saldamente si riallaccia e del quale ancora fa parte'.

${ }^{53}$ It is interesting to note that Silius Italicus's Punica enjoyed no comparable interest during Fascism's imperial endeavours in Africa, in contrast to Pliny the Elder, Sallust, Suetonius and, of course, Livy and Virgil.
} 
The most significant cultural product of Fascist Italy concerning Scipio Africanus and the Second Punic War was Carmine Gallone's film Scipione l'Africano. The film, which has been discussed widely in classical reception scholarship, is viewed as an allegory for Mussolini's victory over Ethiopia. ${ }^{54}$ The paralleling of Mussolini with Scipio goes back at least as far as 1927-the year after the publication of Festa's edition of the Africa-to Giuseppe Petrai's Scipione l'Africano, duce delle legioni romane vittoriose in Africa e in Spagna, which was republished in 1937 to coincide with the release of Gallone's film. The film's production enjoyed the close support and involvement of the regime, with Mussolini's son Vittorio credited as its producer, and so can be seen as encoding a quasi-official ideology of romanità. Scipione l'Africano, and Fascist cinema more generally, was a means by which to disseminate Fascist values of hierarchy, discipline and patriotism. ${ }^{55}$ Scipione l'Africano also helped to popularize the epic history of Scipio Africanus's victory over Hannibal and to make elements of Petrarch's epic available to a mass audience. Now that Italy had its own empire, the Africa would begin to shift in function from being a national poem, which required it to be made accessible to as large a national readership as possible, to an epic of the universal idea of empire. Scipione represents a moment in this developing significance of the Africa.

Giuseppe Pucci, in an article on the history of Scipio on film, highlights the ancient sources for Gallone's film, referring to Livy, Cornelius Nepos, Frontinus, Plutarch and others. ${ }^{56}$ Nevertheless, the place of the Africa as an influence should not be elided. The first reason for this is the demonstrable interest in Petrarch's epic during the ventennio, as I have argued in this article. The second reason is the prominence given in Gallone's film to the story of Massinissa's relationship with Sophonisba. The romance between the Numidian prince, allied to Rome, and the Carthaginian noblewoman is a minor episode in Polybius's account of the Second Punic War (XIV.1.4; XIV.7.6) but is expanded by Livy in his Ab urbe condita (XXX.12-15). Many elements of Livy's narration of the pair's doomed love are found in Gallone's film, from Massinissa meeting with Sophonisba in Syphax's palace at Cirta (XXX.12) and Syphax's attempt to explain his treachery towards Rome as Sophonisba's doing (XXX.13), to Massinissa's torment over whether to hand Sophonisba over to the Romans (XXX.15). ${ }^{57}$ Despite this episode's emotional significance, however, it still constitutes a minor narrative strand in the overall trajectory of Livy's account of Scipio's campaigns. If we compare the space accorded to this story in Livy's account with that of Petrarch's Africa and Gallone's Scipione, we notice an imbalance. Petrarch devotes the entirety of Book Five of the Africa to the romance between Sophonisba and Massinissa, which also spills over into the beginning of

\footnotetext{
54 See, e.g., C. Carabba, Il cinema del ventennio nero, Florence, 1974, pp. 52-64; M. Wyke, Projecting the Past: Ancient Rome, Cinema and History, New York, 1997, pp. 21-2.

55 R. Ben-Ghiat, 'Envisioning Modernity: Desire and Discipline in the Italian Fascist Film', Critical Inquiry, 23, 1996, pp. 109-44.

${ }^{56}$ G. Pucci, 'Splendori e miserie di Scipione l'Africano nel cinema', in Scipione l'Africano: un eroe tra Rinascimento e Barocco, ed. W. Geerts et al., Milan, 2014, pp. 299-309.

57 See S. Haley, 'Livy's Sophonisba', Classica et Mediaevalia, 40, 1989, pp. 171-81, on Livy's characterization of Sophonisba, and a survey of appearances of Sophonisba in Roman texts.
} 
Book Six. He clearly saw this episode as a ripe subject matter for poetic treatment, since he later returned to it in his Trionfi d'Amore. Although much of Petrarch's treatment both in the Trionfi and the Africa is influenced directly by Livy, his Africa shifts the focus from Livy's representation of Scipio's sexual continence to Massinissa's torment and elevates the story to high tragedy.

In Gallone's film, Sophonisba first appears roughly thirty-five minutes in and commits suicide just before the one-hour mark. This places the episode as the central section of the film, chronologically speaking, comparable to the episode's position in the Africa. When we first meet her in the film, we see that, unlike other Carthaginians in Scipione l'Africano, her skin has not been darkened with makeup but is instead dazzlingly white. While, of course, this places her in the visual tradition of DeMille's Cleopatra, the makeup choice holds further interest. If we compare Sophonisba's representation in Scipione with Petrarch's description in the Africa we see similarities: '... Stabat candore nivali, I Frons alto miranda Iovi ...' ('Her brow was as white as snow, admired by lofty Jupiter', V.22-3). ${ }^{58}$ Without labouring the point too much-Sophonisba's representation in Scipione is, after all, in keeping with other exotic femmes fatales of 1920s and 30s cinema-I want to take the comparison of the Africa's and Scipione's Sophonisbas a bit further.

Thomas Green argues that Massinissa's affair with Sophonisba in the Africa is narrated in terms of crossing boundaries. Massinissa enters Cirta like a wolf into a sheepfold (V.6) and meets Sophonisba on the threshold of the palace (V.12). Later, Scipio uses similar language to describe the pervasive insidiousness of the desire elicited by Sophonisba (V.534), while later still, Sophonisba's soul pauses on the threshold of Hades after she commits suicide (VI.51-2). ${ }^{59}$ In Gallone's film, Sophonisba is portrayed in liminal terms. Her whiteness compared with the other North Africa characters, both Carthaginian and Numidian, places Sophonisba in a complex position of being both exotic and familiar, threatening and desirable. When Laelius comes to Syphax's palace on an embassy (the topic of Books Three and Four of Petrarch's epic), Sophonisba is seen on the boundary of this masculine sphere of diplomacy, initially only as a shadow behind a curtain, until she finally transgresses this ideological boundary to offer her counsel to Syphax. As well as standing between Italian self and North African Other, then, she also stands between the feminine sphere of the Orientalising representation of her chambers, a quasi-harem, and the masculine sphere of political leadership. Petrarch highlights Sophonisba's ability to confuse boundaries when he writes: '... uicte uictorem sponte secutum I Coniugia, et bello indomitum seruire puelle' ('the victor had willingly subjugated himself to the defeated and the one undefeated in war served a girl', V.274-5). In Gallone's film, the threat posed by Sophonisba has to be resolved by her death, after which the momentum towards Zama picks up speed. Similarly, not even taking into account the mysterious lacuna between Books Four and Five, the Sophonisba story

\footnotetext{
58 See A. A. Feng, Writing Beloveds: Humanist Petrarchism and the Politics of Gender, Toronto, 2017, pp. 51-2, on Petrarch's Sophonisba and Laura.

59 T. M. Green, 'Petrarch "Viator": The Displacements of Heroism', The Yearbook of English Studies, 12, 1982, pp. 35-57.
} 
line in the Africa requires resolution before we return to Scipio's campaign. In both Gallone's film and Petrarch's epic, Sophonisba and Massinissa's affair is a central episode of the narrative, rather than a brief, but interesting, digression prior to the victory of Zama, as it is in Book Thirty of Livy. Thus, in elevating and centralizing Sophonisba's story within the narrative tapestry of the Second Punic War, Gallone's film follows the example of Petrarch's Africa, suggesting that the poem played an important, though implicit, role in shaping this statement of imperial romanità.

While it would be presumptuous to assert with any certainty that Gallone had Petrarch, rather than Livy, in mind when writing the Sophonisba scenes, we can be sure that Petrarch's epic was circulating widely in discourses of empire and romanità. For example, Arturo Marpicati, who later became the director of the INCF, stated in a 1940 commemorative speech that the Africa had been 'returned to youth ... precisely because of the return of the new Italy into the Africa of the Scipios, ${ }^{60}$ in other words, because Fascist Italy had invaded Africa. The Africa's amenability to Italian colonial discourse was made especially clear in an article published in 1940 in the journal Gli Annali dell'Africa Italiana, which began publication in 1940 to promote Italian imperialism in Africa. Arguing in favour of the relevance of Petrarch's epic for Italian imperialism in Africa, Ignazio Colli writes:

With Petrarch ... the new Italy begins to feel its Roman and Latin roots and to reacquire the conscience of its mission of intellectual and political supremacy over the other peoples of the planet. ${ }^{61}$

Petrarch's epic was thus able to be seamlessly articulated into discourses of Italian supremacy, underpinned by its Roman and Latin roots, and mobilized into the legitimization of empire. The vision of Fascist imperialism could not, however, be contained within the confines of a rigid classicism. Colli, echoing Festa and Carrara, goes on to state:

The Africa is not a humanist work, it is not a return to Rome but is an evolution of the imperial idea which perennially assumes new aspects and reaches new heights. ${ }^{62}$

The relevance of the Africa for Italy's war effort is made explicit towards the end of the short article.

While the radio announces changes in the British high command, we hear news that concerns us in a particular way: Antony Eden has moved into Egypt

\footnotetext{
60 A. Marpicati, L'incoronazione del Petrarca in Campidoglio, Vienna, 1940, p. 24, cited and transl. in Martin (n. 3 above), p. 200. Marpicati had two years previously written a short pamphlet for the Istituto di Studi Romani on Roma nell'opera del Petrarca, Rome, 1938.

61 I. Colli, 'Attualità del poema africano del Petrarca', Gli Annali dell'Africa Italiana, 3.4, 1940, pp. 333-7 (333): 'Col Petrarca ... comincia l'Italia nuova che si sente romana e latina e riacquista conscienza di avere una missione di supremazia intellettuale e politica sugli altri popoli della terrra.'

62 Ibid., p. 337: “'Africa” non è un'opera dell'Umanesimo, non è un ritorno a Roma, ma è l'evoluzione dell'idea imperiale che perennemente assume nuovi aspetti e tocca nuovi vertici.' See also Lee, Humanism and Empire (n. 1 above), pp. 202-9, on humanist conceptions of the universal character of Roman imperium.
} 
to stir up the resistance of the empire. We wait to see what happens next; in the meantime, we re-read Book Two of the Africa ... ${ }^{63}$

Colli then translates lines II.70-76 of the Africa, when, during the dream of Scipio, Scipio's uncle foretells Hannibal's flight to the Hellespont to solicit foreign arms in his fight against Italy. The comparison of Antony Eden with Hannibal is part of the wider Italian discourse during the Second World War of the British Empire as the modern incarnation of the Carthaginian empire, the enemy of Fascism's Roman Empire. ${ }^{64}$

According to Colli's article, then, in the year of Italy's entry into the Second World War, the Africa began to transcend its role as an instrument of Roman revival and came to represent the universal idea of empire. In the context of a global conflict and Fascist Italy's alliance with Nazi Germany, and Imperial Japan, ${ }^{65}$ universal Fascism, as proposed by theorists such as Berto Ricci, must have been seen as an increasingly plausible proposition. For example, Ricci wrote in 1931, prior to the invasion of Ethiopia and Mussolini's proclamation of empire, that

we believe in the political absolute, which is empire. Therefore, we shall be universal and oppose any vestiges of nationalism, we shall be modern and without idols ... It is us up to our century to make Italians think in terms of vastness again. ${ }^{66}$

The notion of empire as an eternal idea, always taking on new forms, mirrors Petrarch's vision of history as a process of constant construction and destruction, as argued by Giuseppe Mazzotta. ${ }^{67}$ Yet, where Ricci opposes universalism to nationalism, Colli's interpretation of the Africa's imperial ideology is rooted in the Italian nation and its Roman history. Therein lay a key tension in how Fascist imperialism used Petrarch's Africa-was it a poem of national renewal, of the rebirth of Rome from the ashes, or of eternal empire, an immortal idea that could never die? This question had more significant ramifications for Fascism itself. Was it an ideology of Italian renewal through a national past, or a universal ideal, necessitating empire and expansion? This would be a question which Italian Fascist imperialism would prove unable to answer itself, before it lost its overseas empire in Africa and the modernday Carthaginians of the Allied forces had swept into the Italian peninsula.

\footnotetext{
63 Colli, 'Attualità' (n. 61 above), p. 337: 'Mentre la radio annunzia mutamenti negli alti comandi britannici, apprendiamo una notizia che ci riguarda in modo particolare: Antonio Eden si è tranferito in Egitto per animare la resistenza dell'impero. Aspettiamo grandi eveni prossimi: intanto rileggiamo il II libro dell' Africa.'

64 Istituto di Studi Romani, I Moderni carthagi. Mare Nostrum II, Rome, 1940.

65 See D. Hedinger, 'Universal Fascism and its Global Legacy. Italy's and Japan's Entangled History in the Early 1930s', Fascism, 2, 2013, pp. 141-60.

66 B. Ricci, 'L'universale', L'Universale, January 1931, cited in E. Gentile, La Grande Italia: The Myth of the Nation in the Twentieth Century, transl. S. Dingee and J. Pudney, Madison WI, 2009, p. 172.

67 G. Mazzotta, 'Petrarca e il discorso di Roma', in Petrarca: Canoni, esemplarità, ed. V. Finucci, Padua, pp. 259-72.
} 


\section{Conclusion: The Africa between Nation and Empire}

In this article, we have seen that interest in Petrarch's Africa can partly be attributed to its characterization as a national poem of Italy. From Foscolo's identification with the words that Petrarch puts in Mago's mouth to the first complete translation of the poem in Italian appearing three years after Rome became the capital of the new nation-state of Italy, in time for the fifth centenary of Petrarch's death, there was a clear momentum gathering behind scholarship on the epic in the nineteenth century, not only in Italy, but in France as well. The years around the sixth centenary of Petrarch's birth were perhaps most significant, in terms of Petrarch's reception under Fascism, for the first steps taken to publish the Edizione nazionale of his complete works. The first volume to appear, Festa's 1926 edition of the Africa, remains the most crucial single piece of scholarship on the Africa to date. It sought to vindicate the poem and to allow it to ascend to the status of Italy's national poem. Petrarch played an important role in the promotion of the Fascist ideology of romanità, refracted through Fascism's mythologization of the medioevo, and efforts were taken to make his epic of Rome's victory over Carthage as accessible as possible. Romanità was a key element of Fascism's project of national renewal, and Petrarch, celebrated as the resuscitator of the spirit of Rome, was therefore an exemplary figure for Fascism's aims to 'excavate modernity'. Thus, in this initial phase of the poem's reception under Fascism, it was its perceived capacity to speak to a national literary identity, through the language of Roman antiquity, that brought this previously neglected epic such attention.

After the invasion of Ethiopia and Mussolini's proclamation of empire, the emphasis on the Africa shifted from what Fascist-and indeed pre-Fascist, liberal Italy_saw as its national character to its latent imperialism. Thus, we see Fascist Italy's most spectacular film, Scipione l'Africano, share its subject matter, in particular the tragic romance between Sophonisba and Massinissa, with Petrarch's epic. With Italy's entrance into the Second World War, Fascist Italy had to take account of its alliances with other empires. In order to extend the ideological potential of the Africa to Italy's allies, Colli made it into something even more universal than the myth of Rome - that of empire. With Italy's loss of empire, the dream of renovatio imperii promoted by Petrarch's Africa once more faded into obscurity.

Acknowledgments This article expands on research conducted during my doctoral studies under the kind, constructive and rigorous supervision of Dr Daniel Orrells and Dr Sebastian Matzner. Dr Elena Giusti provided very thoughtful, helpful and informative comments on a draft, for which I am extremely grateful. Thanks also for the reviewers of the article for their gracious and insightful comments.

Funding Parts of the research for this article were conducted during an Arts and Humanities Research Council (London Arts and Humanities Partnership) funded PhD at King's College London.

Open Access This article is licensed under a Creative Commons Attribution 4.0 International License, which permits use, sharing, adaptation, distribution and reproduction in any medium or format, as long as you give appropriate credit to the original author(s) and the source, provide a link to the Creative Commons licence, and indicate if changes were made. The images or other third party material in this article are included in the article's Creative Commons licence, unless indicated otherwise in a credit line to the material. If material is not included in the article's Creative Commons licence and your intended use is 
not permitted by statutory regulation or exceeds the permitted use, you will need to obtain permission directly from the copyright holder. To view a copy of this licence, visit http://creativecommons.org/licen ses/by/4.0/.

Publisher's Note Springer Nature remains neutral with regard to jurisdictional claims in published maps and institutional affiliations. 